


\section{Judges and \\ Religious-Based Reasoning}

\section{Diana Ginn ${ }^{\star}$ and David Blaikie ${ }^{\star *}$}

Is it ever acceptable for a judge in a secular liberal democracy ${ }^{1}$ to rely on, and explicitly refer to, religious-based reasoning ${ }^{2}$ in reaching a decision? While it is unlikely that many Canadian judges will be seized with the desire to include religious-based reasoning in their judgments, we raise this issue because it allows us to examine the appropriate role of religious-based discourse in a challenging context, where arguments about unconstitutionality are strongest. In a previous article, we concluded that there are no ethical impediments to citizens using such discourse in discussing public affairs. We argued that it is no less virtuous (although it may sometimes be less persuasive) to reason from one's religious convictions than from any other comprehensive set of values, when advocating for or against public policy alternatives. ${ }^{3}$ We would suggest that this is generally also the case for elected representatives. Thus, in our view, it would be perfectly acceptable for a member of a legislature to buttress a call for increased funding for social services by reference to Proverbs 19:17: "One who is gracious to a poor man lends to the Lord." " However, it is unconstitutional for a legislature to pass legislation for a religious purpose $\mathrm{e}^{5}$; therefore, legislators must recognize the distinction between advocating legislation designed to achieve a religious purpose and using religious arguments to support or oppose legislation designed to achieve a public purpose. ${ }^{6}$

The question we address here is whether it would be acceptable for a Canadian judge to use religious-based reasoning and, if so, what parameters might need to be placed on the use of such reasoning. We conclude that the use of religious-based reasoning would be acceptable, but only where the law is underdetermined; that is, where the relevant constitutional principles, legislation and case law do not resolve the issue, and where substantial interpretation and development of the law is required in order to decide the matter before the judge. We would add the further important proviso that the reasoning must conform to the constitutional requirement that the state remain neutral as among different religions and as between religion and non-religion.

We begin our discussion by outlining what we mean by legal underdeterminacy, and then respond to various arguments against allowing religious-based reasoning by judges, with a particular focus on arguments relating to unfairness and unconstitutionality.

\section{When is the law underdetermined?}

We start from the premise that where the law is clear, there is no room (or reason) for a judge to turn to his comprehensive set of beliefs-religious or not-to reach a conclusion. For example, consider a situation where a statute states that it is an offence to drive faster than $110 \mathrm{~km} /$ hour. If the evidence makes it clear that the accused did so, and there are no valid defences put forward, the judge must find the accused guilty; the law is settled and reaching the appropriate verdict requires no reference to extra-judicial fundamental beliefs. Consider another example. A First Nation in Canada makes a land claim based on Aboriginal title. The Supreme Court of Canada has set out a test, based on historic use and occupation of the land, for determining the existence of Aboriginal title. While it may be difficult to decide whether the test has been met in a particular situation, the test itself is clearly 
stated in the law. Therefore, it is the test that any lower court must work with, and a judge cannot turn to her religion-or to any other comprehensive set of values - to craft a new test for determining the existence of Aboriginal title. Nor may judges use their religious-or otherbeliefs to undermine the legal system they are part of. For instance, a judge could not refuse to follow the rule of law because it did not conform with her religious beliefs. If the fundamental principles of the legal system are incompatible with a judge's core beliefs, then she should step down.

Even within an established system of law, however, there will be times when the law is underdetermined. As an example, consider a 1999 decision of the Supreme Court of Canada, Dobson (Litigation Guardian of) v Dobson, ${ }^{7}$ where the Court was called on to develop new legal principles in order to resolve a difficult and significant issue. In Dobson, the Supreme Court of Canada addressed the question of whether a child could sue his mother for harms caused by the mother's negligence during pregnancy. Although previous case law dealt with related issues, there was no Canadian jurisprudence directly on point.

Mrs. Dobson, five months pregnant, was driving her car on a snowy winter day. Her car skidded; there was an accident and her son, Ryan, was born prematurely. Ryan has cerebral palsy; he is profoundly disabled and requires lifetime care. Ryan sued his mother, alleging negligence. If Mrs. Dobson had been found negligent, then her insurers would have had to make a substantial payment to Ryan. First, however, the Supreme Court of Canada had to decide whether Mrs. Dobson was liable in law. Could Ryan sue his mother on the grounds that her negligence during pregnancy caused him harm?

The Supreme Court of Canada was in uncharted legal waters. This was the first time that the Court had been called upon to answer this question and neither the Constitution, relevant legislation, nor case law provided a clear-cut answer. The Court had to decide which of the competing public policy alternatives should prevail, and choosing among those alternatives required making value judgments about how the law could best serve the interests of society, as well as its individual members such as Ryan and his mother.

The majority of the Court refused to extend established principles of tort law in order to allow Ryan to sue his mother. Their decision was based on public policy concerns regarding the privacy and autonomy rights of women, and on the difficulties inherent in articulating a judicial standard of conduct for pregnant women. The two dissenting judges held that concerns about autonomy could not justify placing the rights of a pregnant woman above that of her child. They went on to say: "To grant a pregnant woman immunity from the reasonably foreseeable consequences of her acts for her born alive child would create a legal distortion as no other plaintiff carries such a one-sided burden, nor any defendant such an advantage."8

In Dobson, neither the majority nor the dissenting judgment referred to religious beliefs or values at all-but what if they had? What if the judge writing for the majority had related the public policy argument about autonomy to a religious belief that God has created all of us, male and female, as equal and autonomous beings, equally deserving of respect and dignity? What if the dissenting judges had based their decision on a belief in God's concern for the vulnerable and the powerless? The outcome of the case would have been the same, but the analysis would have been explicitly grounded in religious belief and reasoning. Would express reliance on religious-based reasoning be acceptable in a case such as this?

\section{The arguments against religious- based judicial reasoning}

The key arguments against the explicit use of religious-based reasoning by judges involve concerns about inherent dangers in religious-based reasoning; inconsistency with the role of the judge in a democracy; unfairness to litigants; and threats to freedom of religion. We address each of these, with a particular emphasis on fairness and freedom of religion. 


\section{Inherent dangers in religious-based reasoning}

The argument that religious-based reasoning is inherently more dangerous than other kinds of value-based reasoning seems to encompass three strands: that religious belief requires a leap of faith and thus any reasoning based on religion is inherently more risky than reasoning based on a secular, rational approach; that religious-based reasoning is inherently more divisive than other kinds of argumentation; and that religious-based reasoning is inherently more likely to lead to bad results. ${ }^{9}$

With regard to the first strand, we acknowledge that religious belief involves a leap of faith. By "leap of faith" we mean accepting as true something that is not empirically provable. Rejecting religious-based reasoning on this ground raises the larger epistemological question of whether there are justifiable grounds for saying that certain ways of knowing are superior to others. ${ }^{10}$ There is also the more pragmatic point that the leap of faith argument simply does not work as a means to distinguish religious reasoning from secular reasoning. We take it as given that most people's conclusions about what is right or wrong, what is just, or what course of action is the better one, are grounded in some sort of comprehensive set of values-that is, by fundamental assumptions about the nature of reality, whether religious or secular. ${ }^{11}$ We argue that leaps of faith are required for any such fundamental assumptions and, therefore, this is no different for religion than for other comprehensive belief systems. For instance, it is a core premise of liberalism that all people are entitled to equal rights-presumably because at some fundamental level, all human beings have equal intrinsic value, unrelated to their social status, wealth, character, accomplishments, contributions to society or physical or mental attainments. There is no way of empirically proving this inherent equal value: a leap of faith is required.

Further, while we accept that religious belief is grounded on a leap of faith, when we speak of judges using religious-based reasoning, our emphasis is as much on "reasoning" as on "religious." Whatever fundamental principles form the bedrock of a judge's worldview, judges must reason and analyze - and this is never more so than when the law is underdetermined and it is necessary to turn to extra-judicial values in order to choose between different approaches to the issue in dispute. Even if it is acceptable for judges to make explicit reference to religion when faced with a situation of underdeterminacy, there is still the expectation that reasoning is involved. Thus, we distinguish between a judge moving directly from her understanding of divine will to the outcome (as in "God told me to decide for the plaintiff") $)^{12}$ and a judge, faced with underdeterminacy, using principles derived from his religious beliefs as a starting place for the analysis. ${ }^{13}$ A well-known example of the latter kind of reasoning is found in the landmark case of Donoghue $v$ Stevenson, ${ }^{14}$ where the House of Lords was called on to set the parameters of liability in the newly-emerging field of negligence. The existing law did not provide a clear answer, so Lord Atkin turned to the Golden Rule, stating:

\section{The rule that you are to love your neighbour becomes in law you must not injure your neighbour; and the lawyer's question, Who is my neighbour? receives a restricted reply. You must take reasonable care to avoid acts or omissions which you can reasonably fore- see would be likely to injure your neighbour. Who, then, in law, is my neighbour? The an- swer seems to be-persons who are so closely and directly affected by my act that I ought reasonably to have them in contemplation as being so affected when I am directing my mind to the acts or omissions which are called in question. ${ }^{15}$}

A second danger sometimes attributed to religiousbased reasoning is that it is inherently disruptive. Thus, Richard Rorty claims, "[W]e shall not be able to keep a democratic community going unless the religious believers remain willing to trade privatization for a guarantee of religious liberty." 16 We addressed this argument in our previous article, ${ }^{17}$ and so we need only canvas it briefly here. In short, our response is that religious beliefs are no more divisive than many other strongly held convictions. To understand the absurdity of Rorty's claim we need only substitute another comprehensive, but secular, world view: "We shall not be able to keep a dem- 
ocratic community going unless libertarians are willing to trade privatization for a guarantee of freedom of conscience."

The final strand of the argument that religiousbased reasoning is inherently dangerous focuses less on the reasoning process, or on the reactions of others to that reasoning, and more on the outcomes that are assumed to follow from such reasoning. This fear seems to proceed from the assumption that all individuals of faith hold similar views on social issues-an assumption that is clearly untenable in light of the great diversity of religious beliefs-and that these views are harmful to society. We reject the position that reasoning based on religious beliefs is inherently more likely to lead to bad results than reasoning based, for instance, on conservatism, libertarianism, feminism, or some other secular philosophy. While we acknowledge "the demonstrated, ubiquitous human propensity to be mistaken and even to deceive oneself about what God has revealed," 18 we are convinced that humans are equally capable of using secular reasons to delude themselves into doing terrible things in the name of a greater good. Thus, as "so much of the twentieth century attests, ... one need not be a religious believer to adhere to one's fundamental belief with closed-minded or even fanatical tenacity." 19

\section{The role of judges in a democracy}

Would express use of religious-based reasoning by judges where the law is underdetermined erode the role of judges in a democracy? Democratic values require that a judge be "principled, independent and impartial" ${ }^{20}$ and have a strong respect for the rule of law.

In the context of judging, we take "principled" to mean following and applying accepted legal norms, and deciding on the evidence and argument before the court, rather than deciding on a whim or out of expediency or self-interest. There is no reason to assume that reasons grounded in religious belief would be any less principled than reasons grounded in any other set of comprehensive values.

Independence demands that judges not allow themselves to be pressured by outside enti- ties (including government) into deciding a case in a particular way; to allow external pressure to affect a decision would diminish independence. Judicial independence would certainly be compromised if a judge could be dictated to by a religious organization or faith group. However, allowing a judge to refer explicitly to religious reasoning where the law is underdetermined does not automatically compromise judicial independence.

Impartiality requires that a judge be neutral as between the parties; that is, she cannot be predisposed to favour one party over the other. Certainly, this value would be undermined if a judge, consciously or unconsciously, favoured litigants of a particular religion, or favoured religious litigants generally over non-religious litigants. Again, however, allowing for explicit reliance on religious reasoning where the law itself does not offer sufficient guidance does not lead inevitably to such favouritism. There seems no more reason to assume that judges would allow themselves to be biased on the basis of religion than on the basis of culture, ethnicity, gender, or class. Therefore, the dual response to concerns about bias should be the same for each of these examples: a requirement that judges be self-aware and alive to the possibilities of bias, however unintended; and a concerted effort to appoint a diverse judiciary.

The rule of law is shorthand for a number of concepts limiting the arbitrary power of the state. The most famous expression is that of Dicey, who described the rule of law as requiring the following:

1. the supremacy of regular law as opposed to the influence of arbitrary power, excluding the existence of arbitrariness, prerogative, or even of wide discretionary authority on the part of the government;

2. equality before the law, excluding the idea of any exemption of officials or others from the duty of obedience to the law which governs other citizens;

3. the law of the constitution is not the source but the consequences of the rights of individuals as defined and enforced by the courts. ${ }^{21}$ 
Judicial use of religious-based reasoning where the law is underdetermined would not necessarily increase the arbitrary powers of the state, reduce the obligation of public officials to obey the law, or leave individual rights more vulnerable to state encroachment.

A more modern description of the rule of law is as follows:

The rule of law presupposes that laws will usually be obeyed, that breaches of the law will usually meet with enforcement, that government will be limited in its powers, and that courts and the legal profession will be independent of government and of powerful private interests. ${ }^{22}$

Generally, none of these principles would be diminished if a judge employed religious-based reasoning in the context of legal underdeterminacy; in particular, such reasoning would not make courts more susceptible to pressure from government or private interests. One concern might be that individuals opposed to the particular religious beliefs relied upon, or to all religious beliefs, might then view the law as less legitimate and so be less inclined to obey it. While not dismissing this argument out of hand, we would suggest that the same concern could arise whenever citizens are unhappy with the value system underlying a particular judicial approach; in other words, this is not a concern limited to religious-based judicial reasoning.

\section{Unfairness}

Leaving aside questions of constitutionality, which are discussed below, is it unfair to litigants if a judge makes explicit reference to religious-based reasoning, particularly if relying on a religious tradition not shared by the litigant? Some would argue that religious-based reasoning is unfair because it is inaccessible to those of another religion, or of no religion. We canvassed these arguments in our previous article; ${ }^{23}$ briefly, we suggest that characterizing religious reasoning as inaccessible confuses accessibility with persuasiveness. It is perfectly possible to understand a public policy argument derived from fundamental beliefs which we do not share-we just may not be persuaded by it.
Would express reliance on religious-based reasoning where the law is underdetermined be unfair because it would require appellants, or future litigants in similar cases, to make religious-based arguments even if they did not wish to? It has been argued that "subsequent litigants in analogous hard cases would have to challenge both the court's comprehensive conviction about authentic human existence and its analysis of legal principles in order to prevail." ${ }^{24}$ Arguably, however, by referring to his religious beliefs a judge is simply explaining why he chose one approach over another in a context where the relevant constitutional principles, legislation and case law did not provide a clear guide. Those religious beliefs do not, by virtue of having been referenced in the decision, now become part of the law. If the losing party wished to appeal, she would argue that the lower court decision was wrong in law, but would not need to rebut the lower court judge's "comprehensive conviction about authentic human existence."

This distinction can be seen if we turn again to the issues litigated in the Dobson case. Let us assume that a lower court judge had found against Ryan Dobson because of concern for the autonomy of pregnant women. There are enough statements in the law regarding autonomy of the person for the judge to conclude reasonably that this is a core principle of the legal system; however, she would still have to decide how to balance the mother's autonomy against the harm done to the child, and at the time Dobson was decided, the law had not yet struck that balance. In deciding that concerns for the mother's autonomy outweighed other arguments, the judge might refer explicitly to her belief that God created men and women equal. Since individual autonomy is a core value of Canada's legal system, on appeal Ryan Dobson would have had to argue that women's autonomy would not be undermined by allowing a child in his situation to sue, or that autonomy for the pregnant woman is outweighed by other equally core values. He would not have to persuade the appeal court that the lower court judge was wrong in her conviction that God created men and women equal.

Perhaps the unfairness stems not from concerns about religious-based reasoning becoming 
part of the law, but from the fact that the law can coerce the individual, and that a coercive outcome is illegitimate if it is reached through reasoning from values that the individual does not share. Thus, it has been suggested that "it is fundamentally unfair to coerce people, or to use the corporate authority and power of the state, when the grounds for doing so are not ones that those affected could be expected to accept if they made reasonable judgments." ${ }^{25}$

The idea that state action should be founded on grounds that all reasonable people would accept calls to mind Robert Audi's stricture that, in public debate, virtuous citizens should "seek grounds of a kind that any rational adult citizen can endorse as sufficient to the purpose."26 This requirement would suggest that public reason is, at a minimum, reasoning that is likely to be seen as persuasive or at least reasonable by a broad range of individuals. But is Professor Audi's approach helpful when applied to judges, particularly in a situation of legal underdeterminacy? The very fact that the law is underdetermined suggests that the issue before the courts is a difficult and complex one, involving competing public policy arguments; certainly this was so in the Dobson case. This complexity in itself lessens the likelihood of finding one perspective that is widely accepted. Further, even if wide agreement could be found on an important social issue where the law is still unsettled, this agreement is likely to be at the level of general principles that may not give much assistance in real-life decision making. According to Greenawalt, certain statements such as "happiness is better than pain" seem so widely accepted that someone who rejected them "would seem not to be of sound mind." ${ }^{27}$ This may be so, but, in any real-life clash of interests-which is, after all, what court cases are about-a judge is going to have to consider more pointed questions: In whom do we create happiness? And how? And at what expense to others? What if doing right entails pain? What if all the options available will cause pain or loss to some individual or group and the difficult question is how to allocate that pain? Once a judge is required to answer these more pointed questions, it seems inevitable that the reasons for her decision will be persuasive to some, but completely unpersuasive to others.
Dobson is a good example: the reasoning of both the majority decision and the dissent, although secular, would be hotly contested by some Canadians. There could be significant dispute as to how to weigh and prioritize the competing claims of autonomy versus allowing those who have been harmed by negligence to demand compensation. Thus, we would argue that efforts to find public reasons-that is, reasons that will be widely "endorse[d] as sufficient to the purpose"-are not likely to be successful, once one moves beyond broad generalities. ${ }^{28}$ If that is so, then it seems that fairness, in the context of judging, must mean something other than a requirement that judges who are deciding novel issues of law find grounds for their decisions that will, in fact, be seen as reasonable by everyone, including the losing party. ${ }^{29}$

\section{Unconstitutionality}

Even if our arguments about fairness are accepted, it is still necessary to explore whether reliance by judges on religious-based reasoning when the law is underdetermined would violate section 2(a) of the Canadian Charter of Rights and Freedoms, which states:

Everyone has the following fundamental freedoms:

(a) freedom of conscience and religion. ${ }^{30}$

In other words, even if we cannot hold judges to the standard suggested by Audi for virtuous citizens (by demanding that the basis for their decisions be acceptable to all rational individuals), do constitutional difficulties arise if the coercive power of the state is grounded on reasoning based on religious faith rather than on a secular set of comprehensive values? Is it constitutional for a feminist judge to draw upon his feminism in deciding a new legal issue (even if the losing litigant is profoundly opposed to all feminist principles) but unconstitutional, because of the protection given in section 2(a) of the Charter, for a religious judge to draw upon her faith in deciding an equally novel issue? ${ }^{31}$

Distilling the case law and academic commentary, freedom of religion in Canada includes both a positive aspect ("freedom for religion") and a negative aspect ("freedom from 
religion"). ${ }^{32}$ The positive aspect of freedom of religion, that is, the right to worship and live out one's religion as one wishes, so long as this does not harm another's rights, has been described by the Supreme Court of Canada as including "the right to entertain such religious beliefs as a person chooses, the right to declare religious beliefs openly and without fear of hindrance or reprisal, and the right to manifest religious belief by worship and practice or by teaching and dissemination" ${ }^{\prime 3}$ and the right not to have one's "profoundly personal beliefs" ${ }^{34}$ interfered with. Would the positive aspect of section 2(a) of the Charter-freedom for religion-be infringed if the judges in the Dobson case reasoned from a religious basis in deciding whether a child could sue its mother for harm caused by the mother's negligence during pregnancy? Religious-based reasoning would not have interfered with the litigants' "profoundly personal beliefs" or undermined their right to manifest those beliefs.

The negative aspect of section 2(a), "freedom from religion," protects individuals from direct and indirect coercion. ${ }^{35}$ This aspect of freedom of religion has been interpreted broadly, and it requires the state to be neutral among religions and between religion and non-religion. More specifically, it is unconstitutional for the state to act for a religious purpose, as the Supreme Court of Canada made clear by striking down legislation intended to enforce a Sunday Sabbath. ${ }^{36}$

Where the law is underdetermined, if a judge places some reliance on her religious beliefs in choosing between available options, does that create a form of unconstitutional coercion for the losing litigant who does not share those religious beliefs? Or, taking this further, does it undermine the freedom of religion of citizens more generally-those citizens who do not share the judge's religious views, yet will be affected by the development in the law? We see this as potentially the strongest argument against religious-based reasoning, and we take seriously the need to ensure that judicial reasoning does not fall short of the requirement for neutrality both among religions and between religion and non-religion.

Returning again to Dobson, a judge could place significant weight on the autonomy of pregnant women for secular reasons or for religious reasons. Similarly, a judge could place significant weight on protecting the unborn for secular reasons or for religious reasons. Whichever the outcome, would the judge have acted constitutionally where secular reasoning was used but unconstitutionally where religiousbased reasoning was used? By using his religious faith as a starting place from which to work through the weighing of competing principles in a particular factual context, would the judge have failed the requirement to be neutral among religions or between religion and nonreligion? It is hard to see how the requirement of neutrality would have been breached. The state would not have set one religion above another, nor would it have privileged religion above atheism or agnosticism. Nor would the state be acting for a religious purpose.

The issues may become somewhat more nuanced, however, if religious belief plays some part in the dispute itself or if the case involves issues on which at least some religions have specific teachings. Consider the case of Brockie $v$ Brillinger, ${ }^{37}$ which involved both these aspects. Mr. Brockie, the owner of a printing company, refused to print letterhead and other materials for the Canadian Lesbian and Gay Archives, an organization committed to enhancing the position of gays and lesbians in society by providing "public access to information, records and artifacts, by and about lesbians and gay men in Canada." 3 Mr. Brillinger, the president of the Archives, brought a complaint under the Ontario Human Rights Code ${ }^{39}$ of discrimination on the basis of sexual orientation. At the hearing, Mr. Brockie stated that he had no objection to serving gay or lesbian individuals but that his religious beliefs prevented him from printing material for an organization that advocated for gay and lesbian rights. The adjudicator upheld the complaint and required Mr. Brockie to print the material and to pay $\$ 5,000$ in damages.

Assume that this decision was appealed to the court; the judge hearing the matter would be faced with the difficult matter of balancing two conflicting rights-based claims: Mr. Brillinger claimed that he was being discriminated against on the basis of sexual orientation and 
Mr. Brockie claimed that any attempt by the state to force him to act against his religious principles would violate his freedom of religion. The current law in Canada provides very little guidance as to how these kinds of competing rights claims should be resolved. What if the judge canvassed all relevant constitutional principles, legislation and case law, but none proved conclusive as to which right should trump the other? In deciding which of the rival claims to privilege, it is quite likely that a judge would have to turn (as presumably the adjudicator did, although not explicitly ${ }^{40}$ ) to an extra-judicial set of values. Would the constitutionality of the judge's reasoning depend on whether those values were religious in nature?

One could imagine a judge deciding either way, based on secular grounds: "Creating a just society requires that close attention be paid to the need to uphold the dignity of all individuals, particularly those, like gays and lesbians, who have historically faced oppression and exclusion"; or "A liberal democratic state requires a healthy dose of self-restraint on the part of government and courts; therefore, courts should be very wary of forcing individuals to act against their core beliefs."

It is also possible to imagine a judge deciding either way using religious-based reasoning. Here, however, it may be useful to consider different religious-based formulations and re-emphasize the requirement that legal reasoning of any sort involve actual reasoning rather than simply the stating of conclusions. In deciding for Mr. Brillinger, a judge might start his analysis from the position that "All individuals are part of God's creation and, therefore, in weighing these claims before me, significant weight must be given to safeguarding the dignity of each individual." Another judge might state: "God particularly loves the dispossessed, so the claims of gays and lesbians must always take priority over freedom of religion claims." In deciding for Mr. Brockie, one step in the judge's reasoning might be as follows: "As a believer myself, I understand that Mr. Brockie cannot simply set aside his religious beliefs while operating in the worka-day world. So, while giving serious weight to the harm done to Mr. Brillinger if his business is refused, I will also give serious consideration to the harm caused by forcing an individual to act in opposition to their religious convictions." On the other hand, a judge might decide for Mr. Brockie on the basis that "The Bible prohibits homosexuality and so claims based on sexual orientation must always be subordinated to other claims."

Arguably, the second approach in each pair is problematic in that it suggests the automatic privileging of one kind of claim over another. Such an approach fails to reflect the fact that the law in Canada protects both sexual orientation and religious freedom, and it comes perilously close to deciding a case based on who the parties are rather than on an analysis of the issues at stake. Rather than using one's religious convictions as a lens through which to evaluate competing legal principles, a certain religious belief is substituted for legal analysis. ${ }^{41}$ Further, at least one of these formulations- "The Bible prohibits homosexuality and so claims based on sexual orientation must always be subordinated to other claims"-conflicts with the constitutional requirement of neutrality because it favours one religious doctrine over other possible interpretations of the Bible and over religious teachings from other faiths. Or, to state it differently, the judge could be seen as acting for a religious purpose; that is, deciding in a particular way so as to implement a particular religious rule.

\section{Conclusion}

In this article, we have argued that, within certain parameters, it is acceptable for a judge in a secular liberal democracy to include religiousbased reasoning in a judgment. Perhaps a prior question is whether it is even possible for a religious person to set aside his or her beliefs when making certain sorts of decisions. We are of the view that, on issues of any significance, no one can "bracket" their most fundamental beliefs (whether those are of a religious nature or based on a secular set of core values) when having to choose between two or more available outcomes. ${ }^{42}$ This would suggest that where the law is underdetermined, religious judges will inevitably be influenced by their 
religious beliefs, just as liberal judges will be influenced by their liberalism, humanist judges influenced by their humanist philosophy, and so on. Some authors, such as Mark Modak-Truran, acknowledge "the necessary reliance on religious convictions" where the law is underdetermined, ${ }^{43}$ but argue that this reliance should not be made explicit. We would argue in favour of transparency.

While religious-based reasoning is not inherently dangerous or problematic, the use of such reasoning by judges does raise questions about the role of judges, fairness, and constitutionality, which must be taken seriously.

We conclude that reference to comprehensive values, including religious values, would not undermine the proper role of the judiciary, so long as this reference is limited to situations where the law truly is underdetermined, and so long as there is actual reasoning, not simply a jump from a religious premise to a conclusion. In our view, if these conditions are met, there is nothing in religious-based judicial reasoning that inherently conflicts with the requirement that judges be principled, independent and impartial and have a strong respect for the rule of law.

So long as the same limits are observed, such reasoning is not, in our view, unfair. We reject the notion that there exists some form of "public reason" that would be acceptable to all reasonable individuals. Thus we consider it unrealistic to suggest that fairness requires judicial decisions to be grounded in reasons that would be considered satisfactory by all, including the losing litigants. Where the underdetermined nature of the legal issue at stake requires judges to turn to extra-judicial values as a starting place for their analysis, it is no more unfair to the litigant who does not share the judge's worldview if that analytic framework is based on religious grounds than if it is based on a secular philosophy such as libertarianism or communitarianism.

We also conclude that section 2(a) of the Charter is not automatically violated by religious-based judicial reasoning, assuming the parameters set out above are observed: the judge may only turn to extra-judicial comprehensive values when the law is underdetermined, and must engage in actual analysis and reasoning. The losing litigant's rights "to manifest religious belief by worship and practice or by teaching and dissemination," ${ }^{44}$ and "not to be compelled to belong to a particular religion or to act in a manner contrary to one's religious beliefs," ${ }^{45}$ would not be eroded simply because the judge reasoned from a faith-based worldview. Nor does using such a worldview as the starting place for judicial analysis necessarily depart from the requirement of state neutrality regarding religion and thus result in unconstitutional coercion. We do recognize, however, that certain kinds of religious reasoning could indeed fall short of the constitutional requirement that the state remain neutral among different religions and between religion and non-religion. If a judge used her religious convictions to always side with religious litigants over non-religious litigants, or to side with litigants of a particular faith, this would violate section 2(a) of the Charter (as well as violating more generally the judge's duty of impartiality, not to mention failing to live up to the expectation that judicial reasoning involves actual reasoning). Further, a judge who decided in a certain way so as to uphold a particular tenet of his faith would violate litigants' freedom of religion. If judges are alert to these potential pitfalls, however, we would argue that there is no constitutional breach if a judge relies on religious-based reasoning when faced with a novel question of law to which constitutional principles, legislation and relevant case law provide no answer. In such a situation, a judge must inevitably turn to some set of comprehensive values as a starting place for his analysis of competing public policy arguments and, if the restrictions set out above are adhered to, it is no more inherently dangerous or problematic if those values arise from religious rather than secular convictions.

\section{Notes}

* Associate Professor, Schulich School of Law, Dalhousie University

** Assistant Professor, Schulich School of Law, Dalhousie University We would like to thank Adam Bata, LL.B 2012 (prospective), for his able research and editorial assistance. 
1 We accept Kent Greenawalt's description of a liberal democracy as having the following characteristics: "democratic governance, equality of citizens, freedom of expression and religious exercise, respect for the dignity and autonomy of all people, and the rule of law." Kent Greenawalt, Private Consciences and Public Reasons (New York: Oxford University Press, 1995) at 21 [Greenawalt].

2 For a definition of religious-based reasoning, we find Jonathan Chaplin's discussion helpful, although he is referring to arguments made by citizens and legislators, rather than judges: "The term 'religiously-based arguments' refers to political [we would add 'legal'] arguments whose grounding in religious beliefs is made clear in advancing them. I am not referring therefore to arguments about religion, but to arguments about politics and law, rooted in some religious conviction" [emphasis in original]. Jonathan Chaplin, "Beyond Liberal Restraint: Defending Religiously-Based Arguments in Law and Public Policy" (2000) 33 University of British Columbia Law Review 617 at 620 [Chaplin].

3 David Blaikie \& Diana Ginn, "Religious Discourse in the Public Square" (2006) 15 Constitutional Forum constitutionnel 37 [Blaikie \& Ginn]. For further discussion of these issues in the Canadian context, see Chaplin, supra note 2; for American writing on the subject, see, among others: John Rawls, Political Liberalism (New York: Columbia University Press, 2005); Robert Audi \& Nicholas Wolterstorff, Religion in the Public Square: The Place of Religious Convictions in Public Debate (Lanham, MD: Rowman \& Littlefield, 1997); and Stephen L. Carter, The Culture of Disbelief: How American Law and Politics Trivialize Religious Devotion (Toronto: Random House, 1994) [Carter].

4 New American Standard Bible (Chicago: Moody, 1995).

$5 \quad R v$ Big M Drug Mart Ltd, 1985 CanLII 69 (SCC), [1985] 1 SCR 295 [Big M].

6 Stephen L Newman describes tax reform initiated by a conservative Republican governor. The reform (which, had it passed, would have shifted some of the tax burden from the poor to rich) was based on Governor Riley's belief that oppressive taxing of the poor was unchristian. Newman argues that:

It in no way diminishes the public character of the state's fiscal policy that Riley and conceivably a significant portion of Alabama voters viewed his tax plan as a practical expression of the biblical injunction to succor the poor. It would be a different story if Riley's plan gave preferential treatment to Christians; but the mere fact that a public official and ordinary citizens choose to interpret a legitimate government objective in light of their private religious convictions has no bearing on its political status. Nor did Riley's religious motives in introducing the tax plan undercut its legitimacy. So long as the policy objective is within the scope of the state's authority, its sponsors' motives are irrelevant...

[W] hat is truly key is that public policies serve a legitimate civil interest and do not aim at securing a spiritual benefit... [I]f it is conceded that the ends of a proposed policy are legitimate, what does it matter that the reasons given in support of the policy are private rather than public in Rawls's sense?

Stephen L Newman, "God, Taxes and 'Public Reason"” (Winter 2004) 51 Dissent 64, online: Dissent Magazine $<$ http://www.dissentmagazine. org/article/?article $=401>$ at $65-66$.

71999 CanLII 698 (SCC), [1999] 2 SCR 753 [Dobson].

$8 \quad$ Ibid at para 130.

9 For further discussion of this argument, although not in the context of judging, see Blaikie \& Ginn, supra note 3.

10 For a critique of the characterization of religious claims as irrational, see Francis J Beckwith, "Must Theology Always Sit in the Back of the Secular Bus?: the Federal Courts' View of Religion and Its Status as Knowledge" (2009) 24 Journal of Law \& Religion 547. For an opposing view, see Suzanna Sherry, "The Sleep of Reason" (1996) 84 Georgetown Law Journal 453.

11 Support for this position can be found in the "cultural cognition" theory developed by Dan M Kahan and Donald Bramar ("Cultural Cognition and Public Policy" (2006) 24 Yale Law \& Policy Review 149). Based on their research, Kahan and Bramar conclude that individuals' views on issues of public policy are influenced by (and can be predicted by reference to) their world view; that is, each individual holds a particular worldview and it is that worldview that causes a person to accept or reject competing claims about the risk or efficacy of public policy proposals. Thus, according to Kahan and Bramar: "culture is prior to facts in the cognitive sense that what citizens believe about the empirical consequences of ... policies derives from their cultural worldviews" (at 150). Building on the work of others, Kahan and Bramar classified their research subjects' worldviews as falling along two dimensions-individualistic versus communitarian and hierarchic versus egalitarian (at 157). 
12 As Wendell L Griffen, a judge and Baptist pastor who supports the use of religious-based reasoning by judges, notes in "The Case for Religious Values in Judicial Decision-Making” (1998) 81 Marquette Law Review 513 at 520 [Griffen]: “The devout judge who relies on religious conviction as the sole basis for judicial decision-making is acting as a prelate, not as a jurist."

13 Jonathan Chaplin, supra note 2, seems to be making somewhat the same distinction when he distinguishes between what he calls "confessional discourse" and "political discourse," defining the former as discourse that "proclaims or argues for (religious or secular) doctrines" and the latter as "addressed to the specific content of law and public policy” (at 642). According to Chaplin, judges have a "constitutional duty ... to adopt an impartial attitude to different confessional viewpoints. This does not mean, however, that judges may not be materially led towards a particular legal interpretation by confessional considerations (whether 'religious' or 'secular'), but that their public reasoning must always be sufficiently justifiable by appeal to matters of fact and law" (at 643). He then gives an example based on a particular secular worldview: "a judge who was 'confessionally' committed to secular libertarianism should not allow controversial assertions about the absolute moral autonomy of individual human beings to intrude into her decisions, but rather confine herself to arguments soundly rooted in law and legal principle" (at 644).

$141932 \mathrm{SC}$ (HL) 31, [1932] AC 562 (BAILII).

15 Ibid at 580.

16 Richard Rorty, Philosophy and Social Hope (New York: Penguin, 1999) at 170.

17 Blaikie \& Ginn, supra note 3. See also Chaplin, supra note 2.

18 Michael J Perry, Religion in Politics: Constitutional and Moral Perspectives (New York: Oxford University Press, 1997) at 75.

Michael J Perry, Under God?: Religious Faith and Liberal Democracy (Cambridge: Cambridge University Press, 2003) at 42.

20 Rosalie Silberman Abella, "The Judicial Role in a Democratic State” (2001) 26 Queen's Law Journal 573 at 580.

21 AV Dicey, Introduction to the Study of the Law of the Constitution, $10^{\text {th }}$ ed (London: MacMillan, 1959) at 202-3.

22 Peter W Hogg \& Cara F Zwibel, “The Rule of Law in the Supreme Court of Canada" (2005) 55 University of Toronto Law Journal 715 at 716.

23 Blaikie \& Ginn, supra note 3.

24 Mark Modak-Truran, “The Religious Dimension of Judicial Decision Making and the De Facto Disestablishment" (1998) 81 Marquette Law Review 255 at 285 [Modak-Truran].

25 Greenawalt, supra note 1 at 72 . Note that Greenawalt does not take this position, but simply raises it.

26 Robert Audi, "The State, the Church, and the Citizen" in Paul J Weithman, ed, Religion and Contemporary Liberalism (Notre Dame, Ind: University of Notre Dame Press, 1997) 38 at 48.

27 Greenawalt, supra note 1 at 27.

28 Further, such efforts may also cause us to forget that even the most widely held views can be tragically wrong. If the goal of judging is to seek the best, the most just solution from among those legally available-rather than simply the most popular - then perhaps we need to avoid privileging widely held views over more contentious approaches. After all, in various times and places, the inferiority of women and the legitimacy of slavery have been widely accepted.

29 If the test is only that those affected should (if they made reasonable judgments) find the grounds acceptable, this does not seem to get us very far. After all, who is going to decide on the reasonableness of the individual's judgments (unless we accept the shaky proposition that reasonable means accepted by the majority)?

30 Canadian Charter of Rights and Freedoms, Part I of the Constitution Act, 1982, being Schedule B to the Canada Act 1982 (UK), 1982, c 11, s 2(a).

31 Griffen, supra note 12 at 514 suggests that many "hold the notion that religious values are somehow more offensive to the way that judges decide than economic values, social values, political ideology, or other secular values that influence the way that judicial decisions are reached."

32 Congrégation des témoins de Jéhovah de St-Jérôme-Lafontaine $v$ Lafontaine (Village), 2004 SCC 48, [2004] 2 SCR 650 (CanLII) [Témoins de Jéhovah]. See also David M Brown, "Freedom from or Freedom for?: Religion as a Case Study in Defining the Content of Charter Rights" (2000) 33 University of British Columbia Law Review 551.

33 Big $M$, supra note 5 at para 94.

$34 R v$ Edwards Books and Art Ltd, 1986 CanLII 12 (SCC), [1986] 2 SCR 713 at para 97.

35 Big $M$, supra note 5 at paras 94-95.

36 Ibid.

37 Brockie v Brillinger (No 2) (1999), 37 CHRR D/12 (Ont Bd Inq).

$38 \quad$ Ibid at para 4.

39 Human Rights Code, RSO 1990, c H19.

40 The adjudicator referred to community stan- 
dards-i.e., the fact that Canadian society provides protection against discrimination based on sexual orientation - thus justifying her decision on ostensibly objective standards. Yet, as Iain Benson and Brad Miller point out in their analysis of the case ("The Diminution of Freedom of Religion" LexView (2000) 38, online: Cardus Centre for Cultural Renewal $<$ http:// www.cardus.ca/lexview/article/2256>):

The adjudicator must inevitably rank or prioritize rights which appear to be in conflict. This prioritization is not a judgement which is simply handed to the adjudicator as "publicly-arrived-at community standards embodied in the Code," but can only be the result of the adjudicator's moral reasoning, however rigorous or deficient it might be. The bare fact that "Canadian society" has "seen fit ... to protect the rights of its lesbian and gay members" is no more determinative of this dispute than the bare fact that "Canadian society" has also seen fit to protect the religious convictions of its members; the rights claims conflict and the adjudicator must inevitably reason about the limits and relative importance of each.

41 Presumably too, an automatic privileging or subordinating of certain claims would be equally flawed if it proceeded from a secular basis. See, e.g., Jonathan Chaplin's comments in note 13 , supra.

42 Griffen, supra note 12 at 514, argues that demanding such bracketing "dehumanizes religiously devout judges by requiring them to either abandon the role of religious faith in their concept of moral knowledge or falsely mask the operation of that faith in the deliberative process". See also Carter, supra note 3 at 213-32.

43 Modak-Truran, supra note 24 at 284.

44 Big M, supra note 5 at para 94.

45 Témoins de Jéhovah, supra note 32 at para 65. 